\title{
PENGARUH KUALITAS SUMBER DAYA MANUSIA DAN KARAKTERISTIK USAHA TERHADAP KUALITAS LAPORAN KEUANGAN UKM KABUPATEN LUMAJANG
}

\author{
Nur Fadilah \\ Fakultas Ekonomi, Universitas Muhammadiyah Jember \\ fadilahnur084@gmail.com \\ Submit, 21-02-2019 Accepted, 30-04-2019 Publish, 03-05-2019
}

\begin{abstract}
Small businesses are the backbone of the Indonesian economy. This research was conducted on Lumajang MSMEs. This study aims to determine the effect of four variables namely leadership education level (X1), accounting knowledge (X2), business size (X3) and length of business (X4) on the quality of financial statements. In this study data was collected by means of observations, interviews and questionnaires on 86 respondents, namely Lumajang MSME actors with purposive sampling technique, which aims to determine respondents' perceptions of each variable. The analysis used includes test data instruments (validity test, and reliability test), multiple linear regression analysis, classical assumption test (normality test, multicollinearity test, heteroscedasticity test), and hypothesis testing ( $F$ test, $t$ test, coefficient of determination). From the results of the analysis using regression, it can be seen that the leadership education variable (X1), accounting knowledge (X2), business size (X3) and length of business (X4), all have a positive effect on the quality of financial statements.
\end{abstract}

Keywords : Human Resource Quality, Business Characteristics, Financial Reports

\begin{abstract}
ABSTRAK
Usaha kecil merupakan tulang punggung perekonomian masyarakat Indonesia. Penelitian ini dilakukan pada pelaku UKM Lumajang. Penelitian ini bertujuan untuk mengetahui pengaruh dari empat variabel yaitu jenjang pendidikan pimpinan (X1), pengetahuan akuntansi (X2), ukuran usaha (X3) dan lama usaha (X4) terhadap kualitas laporan keuangan. Dalam penelitian ini data dikumpulkan dengan alat bantu berupa observasi, wawancara dan kuesioner terhadap 86 responden yaitu pelaku UKM Lumajang dengan teknik purpossive sampling, yang bertujuan untuk mengetahui persepsi responden terhadap masing-masing variabel. Analisis yang digunakan meliputi uji instrumen data (uji validitas, dan uji reliabilitas), analisis regresi linear berganda, uji asumsi klasik (uji normalitas, uji multikolinearitas, uji heteroskedastisitas), dan uji hipotesis (uji F, uji t, koefisien determinasi). Dari hasil analisis menggunakan regresi dapat diketahui bahwa variabel jenjang pendidikan pimpinan (X1), pengetahuan akuntansi (X2), ukuran usaha (X3) dan lama usaha (X4), semuanya berpengaruh positif terhadap kualitas laporan keuangan.
\end{abstract}

Kata Kunci : Kualitas SDM, Karakteristik Usaha, Laporan Keuangan 


\section{PENDAHULUAN}

Usaha kecil merupakan tulang punggung perekonomian masyarakat Indonesia. Iklim investasi yang menguntungkan, lingkungan bisnis yang kondusif serta kemudahan akses keuangan merupakan faktor utama yang dapat mengembangkan aktivitas usaha kecil. Krisis ekonomi yang memporak porandakan perekonomian nasional tahun 1997 yang lalu membangkitkan kesadaran pentingnya peran UKM sebagai tulang punggung perekonomian Indonesia. Hal tersebut bisa dilihat dari besarnya kontribusi kegiatan UKM terhadap perekonomian nasional. Untuk 2009, kontribusi UKM mencapai 58,17 persen dari total produk domestik bruto (PDB).

Kualitas laporan keuangan dapat dikatakan baik dan tidak baik dapat dipengaruhi beberapa faktor yakni seperti tingkat pendidikan dan karakteristik usaha, sebab tingkat pendidikan SD 47\% SMP 14\% SMA $21 \%$ S1 $18 \%$ dan rumitnya laporan keuangan juga penyebab dari tidak terlaksananya laporan keuangan. Karakteristik usaha meliputi 2 hal yaitu Lama usaha dan Ukuran usaha. Ukuran usaha asset yang dimiliki sekitar $\leq 50$ juta sedangkan lama usaha min. 5 th (Dinas Koperasi dan UKM Kab. Lumajang, 2015).

Lemahnya kualitas SDM dalam proses penyusunan laporan keuangan UKM tak terkecuali juga terjadi di Kabupaten Lumajang, dimana berdasarkan data Dinas Koperasi dan UKM tahun 2017 meskipun ada sekitar 500an lebih UKM yang beroperasional namun yang bisa menyajikan dan membuat laporan keuangan sesuai dengan Standar Akuntansi Keuangan Entitas Tanpa Akuntabilitas (SAK ETAP) tidak semuanya. Diduga kualitas SDM pegawai berpengaruh disini sehingga UKM tidak bisa menyajikan laporan keuangan setiap tahun. Laporan keuangan padahal merupakan alat dalam pengambilan keputusan pihak manajemen dan menilai kekayaan pelaku usaha selama periode waktu tertentu. Oleh karena itu, Sumber Daya Manusia (SDM) yang kompeten dan berkualitas memainkan peran penting dalam menghasilkan laporan keuangan yang berkualitas.

Menurut penelitian Mulyani (2014); Iswara (2013); Fitriawati dan Anggraini (2011); Rudiantoro dan Siregar (2011) yang menyatakan jenjang pendidikan pimpinan, pengetahuan akuntansi, ukuran usaha, dan lama usaha. Alasan peneliti memilih variabel tersebut adalah karena pimpinan atau pemilik usaha berpengaruh penting dalam mengelola usahanya. Kemampuan dan keahlian pimpinan Usaha Menengah dapat ditentukan dari jenjang pendidikan pimpinan dan pengetahuan akuntansi sehingga digunakan sebagai variabel dalam penelitian ini.

\section{Teori Stakeholder}

Keberadaan stakeholder sangatlah penting bagi UKM, stakeholder yang dimaksud adalah para kreditor seperti pihak bank maupun Lembaga Keuangan Mikro Masyarakat (LKMM). Hal ini berkaitan dengan sumber ekonomi yang diberikan stakeholder yang diberikan perusahaan sebagai dukungan bagi operasi perusahaan. Sumber ekonomi ini bisa berupa modal atau pinjaman yang berupa uang tunai. Untuk mendapatkan dukungan tersebut, maka perusahaan juga harus dapat meningkatkan kepercayaan para stakeholder tehadap kinerja perusahaan. Salah satu cara untuk meningkatkan kepercayaan para stakeholder yaitu dengan menyajikan laporan keuangan yang berkualitas agar kreditor dapat mengetahui secara jelas mengenai halhal yang berkaitan dengan 
pertimbangan pemberian kredit. Namun dalam paraktiknya, kendala UKM dalam menyajikan laporan keuangan yang berkualitas salah satunya adalah faktor minimnya SDM pada suatu entitas.

\section{Kualitas Sumber Daya Manusia}

Kualitas sumber daya manusia merupakan suatu kemampuan sumber daya manusia untuk melaksanakan suatu tugas dan tanggung jawab yang diberikan kepadanya dengan bekal pendidikan, pelatihan, dan pengalaman yang cukup memadai. Dalam pengelolaan keuangan usaha yang baik, manajer maupun pegawai harus memiliki sumber daya manusia yang kompeten, yang didukung dengan jenjang pendidikan yang ditempuh, sering mengikuti pelatihan dan pendidikan, serta mempunyai pengalaman dan pengetahuan dibidang keuangan (Putri, 2015).

\section{Pengetahuan Akuntansi}

Pengetahuan

akuntansi

merupakan suatu hal yang sangat diperlukan oleh seorang manajer atau pemilik perusahaan dalam menjalankan operasional perusahaan. Motivasi untuk mempelajari tentang pengetahuan akuntansi akan meningkatkan pemahaman manajer atau pemilik dalam penerapannya di perusahaan (Spiker, dalam Fitriyah, 2006). Pimpinan membutuhkan pengetahuan akuntansi untuk dapat menghasilkan suatu laporan keuangan yang bermanfaat bagi penggunanya.

\section{Karakteristik Usaha \\ Ukuran Usaha}

Ukuran usaha merupakan suatu kemampuan usaha dalam mengelola usahanya dengan melihat total aset, berapa jumlah karyawan yang dipekerjakan dan berapa besar pendapatan yang diperoleh perusahaan dalam satu periode akuntansi. Jumlah pendapatan atau penjualan usaha yang dapat menunjukkan perputaran aset atau modal yang dimiliki oleh perusahaan, sehingga semakin besar pendapatan atau penjualan yang diperoleh perusahaan semakin besar pula tingkat kompleksitas perusahaan dalam menggunakan informasi akuntansi.

\section{Lama Usaha}

Lama usaha adalah lamanya suatu perusahaan berdiri atau umur dari perusahaan semenjak usaha tersebut berdiri sampai pada saat penulis melakukan penelitian ini. Dengan asumsi bahwa semakin lama usaha tersebut berjalan maka akan mengakibatkan adanya perkembangan usaha yang signifikan kearah yang positif atau negatif.

\section{Kualitas Laporan Keuangan}

Kualitas laporan keuangan yang baik harus sesuai dengan standar yang telah ditetapkan, yakni SAK ETAP yang ditujukan untuk entitas-entitas tanpa akuntabilitas publik. Iswara (2013) menyatakan pelaporan keuangan berkualitas, jika usaha memiliki laporan keuangan yang lengkap atau utuh dan memenuhi karakteristik kualitatif informasi laporan keuangan yang terdapat dalam SAK ETAP.

Berdasarkan penjelasan di atas maka dirumuskan hipotesis sebagai berikut :

H1: Semakin tinggi Jenjang Pendidikan pimpinan semakin baik kualitas laporan keuangan.

$\mathrm{H} 2$ : Semakin tinggi Pengetahuan Akuntansi semakin baik kualitas laporan keuangan

H3: Semakin tinggi Ukuran Usaha semakin baik kualitas laporan keuangan

H4: Semaki tinggi Lama Usaha semakin baik Kualitas Laporan Keuangan.

\section{METODE PENELITIAN}

Jenis data yang digunakan pada penelitian ini adalah data subyek. Data 
subyek. Sumber data pada penelitian ini adalah data primer. Variabel dependen dalam penelitian ini adalah kuliatas Laporan Keuangan. Sedangkan variabel independen dalam penelitia ini adalah Jenjang Pendidikan, Pengetahuan Akuntansi, Ukuran Usaha, dan Lama Usaha.

Populasi dalam penelitian ini 572 UKM yang berada di Kabupten Lumajang dan Sampel dalam penelitian ini 86 responden yang sudah terdaftar di Dinas Koperasi dan UKM Kabupaten Lumajang.

\section{Metode Analisis Data}

Metode analisis data yang digunakan dalam penelitian ini adalah analisis kuantitatif. Analisis deskriptif dilakukan untuk mengetahui dispersi dan distribusi data. Sedangkan uji asumsi klasik dilakukan untuk menguji kelayakan model regresi yang selanjutnya akan digunakan untuk menguji hipotesis penelitian (Ghozali 2011).

\section{HASIL DAN PEMBAHASAN Uji Validitas}

Uji validitas digunakan untuk menguji sejauh mana ketepatan alat pengukur dapat mengungkapkan konsep gejala/kejadian yang diukur. Item kuesioner dinyatakan valid apabila nilai $r$ hitung $>r$ tabel $(n-2)$.

\section{Uji Relibilitas}

Uji Reliabilitas digunakan untuk menguji sejauh mana kehandalan suatu alat pengukur untuk dapat digunakan lagi untuk penelitian yang sama. Pengujian reliabilitas dalam penelitian ini adalah dengan menggunakan rumus alpha. Hasil pengujian reliabilitas untuk masing-masing variabel yang diringkas pada tabel berikut ini:
Tabel 1. Hasil Pengujian Reliabilitas

\begin{tabular}{lllll}
\hline No & Variabel & $\begin{array}{c}\text { Alpha } \\
\text { hitung }\end{array}$ & $\begin{array}{l}\text { Standart } \\
\text { alpha }\end{array}$ & Keterangan \\
\hline 1 & $\begin{array}{l}\text { Pengetahuan } \\
\text { akuntansi } \\
\text { (X2) }\end{array}$ & 0,926 & 0,700 & Reliabel \\
\hline 2 & $\begin{array}{l}\text { Kualitas } \\
\text { Laporan } \\
\text { Keuangan } \\
\text { (Y) }\end{array}$ & 0,832 & 0,700 & Reliabel \\
& & & \\
\hline
\end{tabular}

Sumber: Data diolah 2018

Hasil uji reliabilitas tersebut menunjukkan bahwa semua variabel mempunyai koefisien Alpha yang cukup atau memenuhi kriteria untuk dikatakan reliabel yaitu di atas 0,700, sehingga untuk selanjutnya item-item pada masing-masing konsep variabel tersebut layak digunakan sebagai alat ukur.

\section{Regresi linier berganda}

Analisis regresi digunakan untuk menguji hipotesis tentang pengaruh secara parsial variabel bebas terhadap variabel terikat. Berdasarkan estimasi regresi linier berganda dengan program SPSS versi 20,0 diperoleh hasil sebagai berikut:

Tabel 2 Hasil Analisis Regresi Linier Berganda

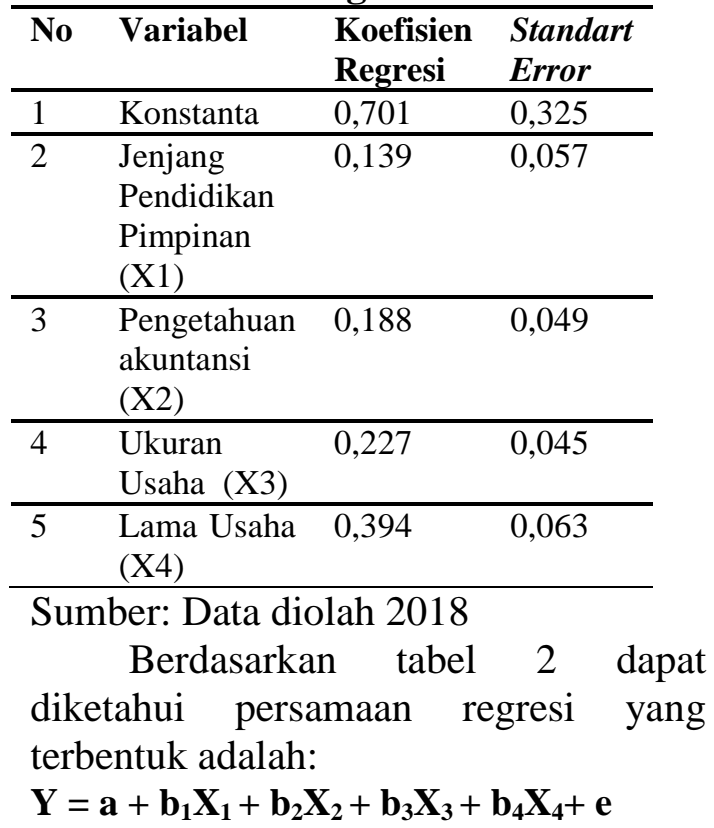


$\mathrm{Y}=\mathbf{0 , 7 0 1}+\mathrm{b} \mathbf{0 , 1 3 9}+\mathrm{b} \mathbf{0 , 1 8 8}+\mathrm{b} 0,227+$ b $0,394+$ e 0,325

Keterangan:

$\mathrm{Y}=$ Kualitas laporan keuangan

$\mathrm{a}=$ Konstanta

$\mathrm{X} 1$ = Jenjang pendidikan pimpinan

$\mathrm{X} 2=$ Pengetahuan akuntansi

X3 = Ukuran usaha

X4 = Lama usaha

$\mathrm{e}=$ Faktor pengganggu

Dari persamaan tersebut dapat diartikan bahwa:

1. Konstanta sebesar 0,701 menunjukkan besarnya kualitas laporan keuangann pada saat sama dengan nol.

2. $\mathrm{b} 1=0,139$ artinya meningkatnya jenjang pendidikan pimpinan per satuan akan meningkatkan kualitas laporan keuangan sebesar 0,139 satuan, dengan asumsi pengetahuan akuntansi, ukuran usaha, dan lama usaha konstan. Hal ini juga mengindikasikan bahwa jenjang pendidikan pimpinan berpengaruh positif terhadap kualitas laporan keuangan yang berarti semakin baik jenjang pendidikan pimpinan akan berdampak pada semakin baiknya kualitas laporan keuangan dengan asumsi pengetahuan akuntansi, ukuran usaha, dan lama usaha konstan.

3. $\mathrm{b} 2=0,188$ artinya meningkatnya pengetahuan akuntansi per satuan akan meningkatkan kualitas laporan keuangan sebesar 0,188 satuan, dengan asumsi jenjang pendidikan pimpinan, ukuran usaha, dan lama usaha konstan. Hal ini juga mengindikasikan bahwa pengetahuan akuntansi berpengaruh positif terhadap kualitas laporan keuangan yang berarti semakin baik pengetahuan akuntansi akan berdampak pada semakin baiknya kualitas laporan keuangan dengan asumsi jenjang pendidikan pimpinan, ukuran usaha, dan lama usaha konstan.

4. $\mathrm{b} 3=0,227$ artinya meningkatnya ukuran usaha per satuan akan meningkatkan kualitas laporan keuangan sebesar 0,227 satuan, dengan asumsi jenjang pendidikan pimpinan, pengetahuan akuntansi, dan lama usaha konstan. Hal ini juga mengindikasikan bahwa ukuran usaha berpengaruh positif terhadap kualitas laporan keuangan yang berarti semakin baik ukuran usaha akan berdampak pada semakin baiknya kualitas laporan keuangan dengan asumsi jenjang pendidikan pimpinan, pengetahuan akuntansi, dan lama usaha konstan.

5. $\mathrm{b}=0,394$ artinya meningkatnya lama usaha per satuan akan meningkatkan kualitas laporan keuangan sebesar 0,394 satuan, dengan asumsi jenjang pendidikan pimpinan, pengetahuan akuntansi, dan ukuran usaha konstan. Hal ini juga mengindikasikan bahwa lama usaha berpengaruh positif terhadap kualitas laporan keuangan yang berarti semakin baik psiologis akan berdampak pada semakin baiknya kualitas laporan keuangan dengan asumsi jenjang pendidikan pimpinan, pengetahuan akuntansi, dan ukuran usaha konstan.

6. $\mathrm{e}=0,325$ artinya besarnya kesalahan dalam model regresi

Uji F, Uji T, dan Koefisien dterminasi Tabel 3. Uji F

\begin{tabular}{llll}
\hline No & Kriteria & & Keterangan \\
\hline 1 & F hitung & F tabel & Signifikan \\
& $(8,600)$ & $(2,4830)$ & \\
\hline 2 & Nilai & Taraf & Signifikan \\
& signifikansi & signifikansi & \\
& $(0,000)$ & $(0,05)$ & \\
\hline
\end{tabular}

Sumber: data diolah 2018

Berdasarkan tabel 3 dapat dilihat

bahwa $F_{\text {hitung }}>F_{\text {tabel }}(8,600>2,4830)$ maka jenjang pendidikan pimpinan, pengetahuan akuntansi, ukuran usaha, 
dan lama usaha mempunyai pengaruh signifikan terhadap kualitas laporan keuanganpada tingkat signifikan 5\%, dalam hal ini $\mathrm{H}_{0}$ ditolak. Sehingga, hipotesis yang menyatakan jenjang pendidikan pimpinan, pengetahuan akuntansi, ukuran usaha, dan lama usaha mempunyai pengaruh signifikan terhadap kualitas laporan keuangan terbukti kebenarannya (H1 diterima).

Tabel 4. Hasil Uji t

\begin{tabular}{lllllll}
\hline No & Variabel & $\begin{array}{l}\text { sig } \\
\text { Hitung }\end{array}$ & $\begin{array}{l}\text { Taraf } \\
\text { sig }\end{array}$ & $\begin{array}{l}\text { t } \\
\text { hitung }\end{array}$ & t tabel & Ket \\
\hline 1 & $\begin{array}{l}\text { Jenjang } \\
\text { pendidika } \\
\text { n } \\
\text { pimpinan }\end{array}$ & 0,017 & 0,05 & 2,435 & 1.6636 & Sig \\
& & & & & \\
\hline 2 & $\begin{array}{l}\text { Pengetahu } \\
\text { an } \\
\text { akuntansi }\end{array}$ & 0,000 & 0,05 & 3,876 & 1.6636 & Sig \\
& $\begin{array}{l}\text { Ukuran } \\
\text { usaha }\end{array}$ & 0,000 & 0,05 & 5,031 & 1.6636 & Sig \\
\hline 4 & $\begin{array}{l}\text { Lama } \\
\text { usaha }\end{array}$ & 0,000 & 0,05 & 6,302 & 1,6636 & Sig \\
\hline
\end{tabular}

Sumber: Data diolah 2018

Dari tabel 4. diketahui perbandingan antara taraf signifikansi dengan signifikansi tabel adalah sebagai berikut:

1. Hasil uji jenjang pendidikan pimpinan mempunyai nilai signifikansi hitung sebesar 0,0017 dan lebih kecil dari 0,05 dan $\mathrm{t}$ hitung $(2,435)>\mathrm{t}$ tabel (1.6636) yang berarti bahwa hipotesis jenjang pendidikan pimpinan mempunyai pengaruh signifikan terhadap kualitas laporan keuangan diterima. Hal ini juga menunjukkan bahwa jenjang pendidikan pimpinan mempengaruhi kualitas laporan keuangan yang berarti semakin baik jenjang pendidikan pimpinan akan berdampak pada semakin baiknya kualitas laporan keuangan.

2. Hasil uji pengetahuan akuntansi mempunyai nilai signifikansi hitung sebesar 0,000 dan lebih kecil dari 0,05 dan $\mathrm{t}$ hitung $(3,876)>\mathrm{t}$ tabel (1.6636) yang berarti bahwa hipotesis pengetahuan akuntansi mempunyai pengaruh signifikan terhadap kualitas laporan keuangan diterima. Hal ini juga menunjukkan bahwa pengetahuan akuntansi mempengaruhi kualitas laporan keuangan yang berarti semakin baik pengetahuan akuntansi akan berdampak pada semakin baiknya kualitas laporan keuangan.

3. Hasil uji ukuran usaha mempunyai nilai signifikansi hitung sebesar 0,000 dan lebih kecil dari 0,05 dan $\mathrm{t}$ hitung $(5,031)>\mathrm{t}$ tabel (1.6636) yang berarti bahwa hipotesis ukuran usaha mempunyai pengaruh signifikan terhadap kualitas laporan keuangan diterima. Hal ini juga menunjukkan bahwa ukuran usahamempengaruhi kualitas laporan keuangan yang berarti semakin baik ukuran usaha akan berdampak pada semakin baiknya kualitas laporan keuangan.

4. Hasil uji lama usaha mempunyai nilai signifikansi hitung sebesar 0,000 dan lebih kecil dari 0,05 dan $\mathrm{t}$ hitung $(6,302)>\mathrm{t}$ tabel (1.6636) yang berarti bahwa hipotesis lama usaha mempunyai pengaruh signifikan terhadap kualitas laporan keuangan diterima. Hal ini juga menunjukkan bahwa lama usahamempengaruhi kualitas laporan keuangan yang berarti semakin baik lama usahaakan berdampak pada semakin baiknya kualitas laporan keuangan.

\section{Uji Koefisien determinasi}

\section{Tabel 5. Hasil uji \\ KoefisienDeterminasi}

\begin{tabular}{llc}
\hline No & Kriteria & Koefisien \\
\hline 1 & R & 0,546 \\
\hline 2 & R Square & 0,298 \\
\hline 3 & Adjusted R Square & 0,263 \\
\hline \multicolumn{3}{c}{ Sumber: Data diolah 2018 } \\
Hasil perhitungan regresi pada \\
tabel 5 dapat diketahui bahwa koefisien \\
determinasi yang diperoleh sebesar
\end{tabular}


0,263 . Hal ini berarti $26,3 \%$ variasi variabel kualitas laporan keuangandapat dijelaskan oleh jenjang pendidikan pimpinan, pengetahuan akuntansi, ukuran usaha, dan lama usaha, sedangkan sisanya sebesar 0,737 atau $73,7 \%$ diterangkan oleh variabel lain yang tidak diajukan dalam penelitian ini.

Berdasarkan hasil pengujian secara statistik dapat terlihat dengan jelas bahwa secara parsial, semua variabel bebas berpengaruh terhadap variabel terikat. Pengaruh yang diberikan keempat variabel bebas tersebut bersifat positif artinya semakin baik jenjang pendidikan pimpinan, pengetahuan akuntansi, ukuran usaha, dan lama usaha maka mengakibatkan semakin baik pula kualitas laporan keuangan. Hasil tersebut sesuai dengan hipotesis yang diajukan. Hasil penelitian ini juga sesuai dengan hasil penelitian sebelumnya. Penjelasan dari masing-masing pengaruh variabel dijelaskan sebagai berikut:

1. Pengaruh jenjang pendidikan pimpinan terhadap kualitas laporan keuangan. Hasil pengujian hipotesis telah membuktikan terdapat pengaruh jenjang pendidikan pimpinan terhadap kualitas laporan keuangan. Melalui hasil perhitungan yang telah dilakukan diperoleh taraf signifikansi sebesar 0,017 dan lebih kecil dari 0,05 dan $t$ hitung $(2,435)>$ $\mathrm{t}$ tabel (1.6636) yang berarti hipotesis diterima. Pengujian secara statistik ini membuktikan bahwa jenjang pendidikan pimpinanberpengaruh terhadap kualitas laporan keuangan, artinya bahwa ada pengaruh jenjang pendidikan pimpinan terhadap kualitas laporan keuangan. Hal ini juga sejalan dengan penelitian oleh Fitriawati dan Anggraini (2011) dan juga sejalan dengan penelitian Rudiantoro dan Siregar (2011). Hasil dari penelitian tersebut membuktikan bahwa jenjang pendidikan pimpinan berpengaruh terhadap kualitas laporan keuangan.

2. Pengaruh pengetahuan akuntansi terhadap kualitas laporan keuangan. Hasil pengujian hipotesis telah membuktikan terdapat pengaruh sial terhadap kualitas laporan keuangan. Melalui hasil perhitungan yang telah dilakukan diperoleh taraf signifikansi sebesar 0,000 dan lebih kecil dari 0,05 dan $t$ hitung $(3,876)>\mathrm{t}$ tabel (1.6636) yang berarti hipotesis diterima. Pengujian secara statistik ini membuktikan bahwa adanya pengaruh pengetahuan akuntansi terhadap kualitas laporan keuangan, artinya bahwa ada pengaruh pengetahuan akuntansi terhadap kualitas laporan keuangan. Hal ini juga sejalan dengan penelitian oleh Rudiantoro dan Siregar (2011) dan juga sejalan dengan penelitian Iswara (2013). Hal ini menunjukkan bahwa pengaruh pengetahuan akuntansi berpengaruh terhadap kualitas laporan keuangan.

3. Pengaruh ukuran usaha terhadapkualitas laporan keuangan. Hasil pengujian hipotesis telah membuktikan terdapat pengaruh ukuran usaha terhadapkualitas laporan keuangan. Melalui hasil perhitungan yang telah dilakukan diperoleh taraf signifikansi sebesar 0,000 dan lebih kecil dari 0,05 dan $\mathrm{t}$ hitung $(5,031)>\mathrm{t}$ tabel (1.6636) yang berarti hipotesis diterima. Pengujian secara statistik ini membuktikan bahwa adanya pengaruh ukuran usaha terhadap kualitas laporan keuangan, artinya bahwa ada pengaruh ukuran usaha terhadap kualitas laporan keuangan. Hal ini juga sejalan dengan penelitian terdahulu yang dilakukan olehIswara (2013) dan sejalan dengan penelitian 
Rudiantoro dan Siregar (2011). Hal ini menunjukkan bahwa ukuran usaha berpengaruh terhadap kualitas laporan keuangan.

4. Pengaruh lama usaha terhadap kualitas laporan keuangan. Hasil pengujian hipotesis telah membuktikan terdapat pengaruh lama usaha terhadap kualitas laporan keuangan. Melalui hasil perhitungan yang telah dilakukan diperoleh taraf signifikansi sebesar 0,000 dan lebih kecil dari 0,05 dan t hitung $(6,302)>$ $\mathrm{t}$ tabel (1.6636) yang berarti hipotesis diterima. Pengujian secara statistik ini membuktikan bahwa adanya pengaruh lama usaha terhadap kualitas laporan keuangan,artinya bahwa ada pengaruh lama usaha terhadap kualitas laporan keuangan. Hal ini juga sejalan dengan penelitian terdahulu yang dilakukan oleh Mulyani (2014)dan Fitriawati dan Anggraeni (2011). Hal ini menunjukkan bahwa lama usaha berpengaruh terhadap kualitas laporan keuangan.

5. Pengaruh jenjang pendidikan pimpinan, pengetahuan akuntansi, ukuran usaha, dan lama usaha terhadap kualitas laporan keuangan.Hasil pengujian hipotesis telah membuktikan terdapat pengaruh iklan jenjang pendidikan pimpinan, pengetahuan akuntansi, ukuran usaha, dan lama usahaterhadapkualitas laporan keuangan. Melalui hasil perhitungan yang telah dilakukan diperoleh taraf signifikansi sebesar 0,000 dan lebih kecil dari 0,05 dan $\mathrm{F}$ hitung $(8,600)>$ F tabel (2,4380) yang berarti hipotesis diterima. Pengujian secara statistik ini membuktikan bahwa jenjang pendidikan pimpinan, pengetahuan akuntansi, ukuran usaha, dan lama usahamempunyai pengaruh terhadapkualitas laporan keuangan, artinya bahwa ada pengaruh antara jenjang pendidikan pimpinan, pengetahuan akuntansi, ukuran usaha, dan lama usaha terhadap kualitas laporan keuangan. Hal ini menunjukkan bahwa penidikan pimpinan pengetahuan akuntansi ukuran usaha dan lama usaha berpengaruh terhadap kualitas laporan keuangan (Rudiantoro \& Siregar, 2011).

\section{PENUTUP}

\section{Kesimpulan}

Dari pengujian secara statistik yang telah dilakukan, maka dapat ditarik kesimpulan sebagai berikut:

1. Jenjang pendidikan pimpinan berpengaruh signifikan secara parsial tehadap kualitas laporan keuangan.

2. Pengetahuan akuntansi berpengaruh signifikan secara parsial tehadap kualitas laporan keuangan.

3. Ukuran usaha berpengaruh signifikan secara parsial tehadap kualitas laporan keuangan.

4. Lama usaha berpengaruh signifikan secara parsial tehadap kualitas laporan keuangan.

5. Jenjang pendidikan pimpinan, pengetahuan akuntansi, ukuran usaha, dan lama usaha berpengaruh signifikan secara simultan tehadap kualitas laporan keuangan.

\section{Saran}

Berdasarkan penelitian yang telah dilakukan oleh peneliti, maka saran yang dapat diberikan kepada pihak pelaku UKM Lumajang dan peneliti selanjutnya dari penelitian ini, yaitu berupaya mempertahankan atau meningkatkan beberapa hal berikut ini:
1. Peningkatan kualitas laporan keuangan.

2. Mempromosikan usahanya. 


\section{DAFTAR PUSTAKA}

Fitriyah. (2006). Analisis faktor-faktor yang mempengaruhin penggunaan informasi akuntansi pada usaha menengah Kab. Sidoarjo. Tesis. Universitas Air langga. Surabaya.

Ghozali, Imam. (2011). Aplikasi Analisis Multivariate dengan Program SPSS. Semarang: Universitas Diponegoro.

Ikatan Akuntansi Indonesia. (2009). Standar Akuntansi Keuangan. PSAK No 1. Penyajian laporan Keuangan. Jakarta: Salemba Empat.

Iswara. (2013). Faktor-Faktor yang Mempengaruhi Kualitas Pelaporan Keuangan Usaha Menengah Kabupaten Jember. UNY.

Putri, Febrina Prima. (2015). Pengaruh Pengetahuan Auditor, Pengalaman Auditor, Kompleksitas Tugas, Locus Of Control, dan Tekanan Ketaatan Terhadap Audit Judgment. Jurnal Fakultas Ekonomi. Universitas Riau. Pekanbaru.

Rudiantoro dan Siregar, (2011). Kualitas Laporan Keuangan Umkm Serta Prospek Implementasi SAK ETAP. Jurnal Keuangan dan Akuntansi. Universitas indonesia. 